\title{
An Experimental Study of the Form of the Human Tibia from the Biomechanical Point of View
}

\author{
Tasuku Kimura
}

INTRODUCTION

Since the latter half of the nineteenth century, the functional analysis of bone form and structure has attracted many investigators specialized in the bone. WolfF established the law of bone transformation in 1892. He maintained that every change of a bone in its function results in changes in the orientation of the trabeculae and in the external form of the bone, Roux (1883) mentioned the functional form of the bone and presented the maximum-minimum theory. According to the theory, the most functional structure is such as to perform the maximum amount of work with the minimum quantity of materials and energy.

After KocH's classic work (1917), many works have been done on the femur, especially on its head, from the biomechanical point of view. But only a few studies has been made on the tibia (PAUwels 1950, KNESE et al. 1954, Kummer 1965). The method of these works was the mathematical analysis, and not the experimental analysis of intact bones.

This paper deals with the intact tibia of man in respect of its functional form by means of the analysis of strains. The fibula is excluded from the subject in this paper, because it may have small significance in mechanical structure of lower limbs.

\section{MATERIALS AND METHODS}

Materials used in the experiments were four macerated right tibiae of Japanese adults. No pathological features could be seen of them.

Strains were measured by means of electric wire strain gages. Three axial gages, for the magnitude and direction of principal strains, and single axial gages for the magnitude of longitudinal strains, were attached to the tibia. Measuring points were selected from following 84 points (Fig. 1): twelve points on each of seven horizontal levels, that is, eight points around the physiological axis and four most prominented points. Shinkoh PS7/L Strain Indicater was used for the measurement.

The main functions of human lower limbs may be to support the standing posture and the walking movement. Forces were accordingly applied to the tibia, which corresponded to those produced to the tibia in certain phases in walking movement. The axial force only was applied to the tibia to make comparison 
with forces in walking. This phase could be approximately similar to that of normal standing posture.

A special apparatus was made for loading the tibia (Fig. 2). Canvas sheets were glued to attaching areas of muscles to the bone. The forces, corresponding to those which are transmitted to the tibia through articulations in living body, were impressed to the tibia by the lever of this apparatus. Forces corresponding to muscular ones were applied through canvas sheets. In this way, the forces approximately similar to those produced in the living body were applied simultaneously to the tibia in this experiment.

The magnitude and direction of the forces in the experiment were selected and arranged in the following way. On the tibia, normal and shearing forces in upper and lower articular surfaces were impressed mainly by the body weight, and tensile forces of muscle
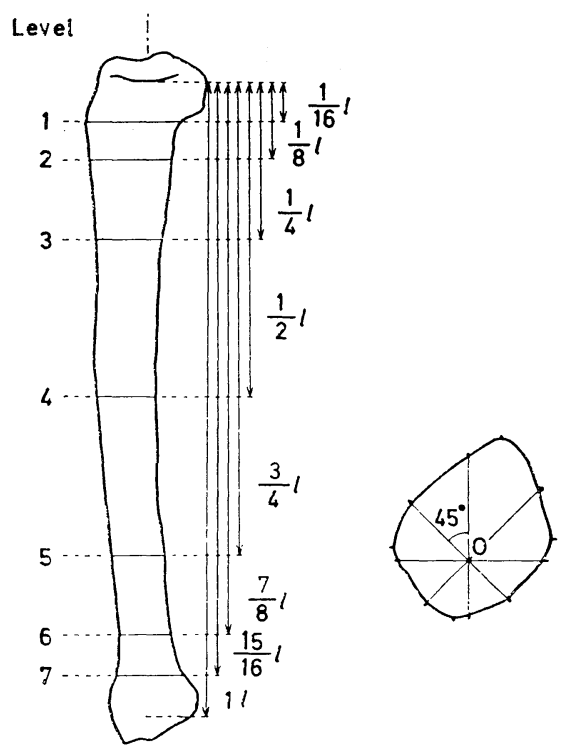

0

Fig. 1. Measuring points of the tibia. On each level, eight points around the physiological axis and four most prominented points were selected as measuring points. $O$; mechanical axis. 1; length between the upper and lower articular sur. faces.

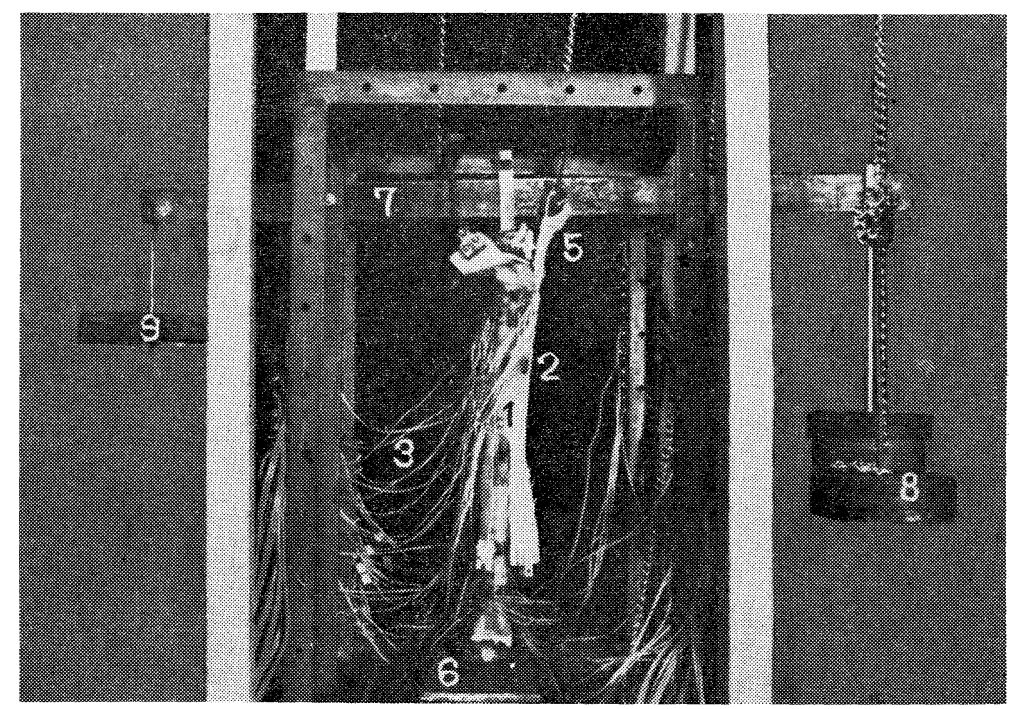

Fig. 2. Loading apparatus.

1) tibia. 2) electric wire strain gages. 3) electrical cords for strain gages.

4) loading piese attached to articular surfaces of the tibia. 5) canvas sheets.

6) roller support which balances the forces. 7) lever. 8) weights for loading.

9) balancing weight. 
groups acted on. The muscle groups acting on were chosen mainly for two reasons. The one was their largeness in the area of the physiological section as compared with other muscles (cited in FICK 1921), the other was their strong activity in walking judged from the electromyography (cited in Kondo 1952 and 1960, Mochizuki 1965). The following six muscle groups were chosen in the experiment: M.quadriceps femoris; M. biceps femoris; Mm. semimembranosus et semitendinosus; M. tibialis anterior; M. gastrocnemius: $M$. soléus.

It is very difficult to know the magnitude of muscle forces in living body. Hence, I inferred it from the mathematical analysis by means of force equilibrium as many authors have tried (e. g. KNESE 1955, KuMMER 1959). Three phases were picked up for the analysis from a series of phases in the walking diagram made by BRAUnE et FISCHER (1895) and Fischer (1899) Those were phases of No. 13, No. 16 and No. 20 from the 1st trial. The knee was flexed greatly and the ankle was extended extremely in No. 13. The center of foot pressure was at the heel. The knee was extended greatly and the ankle was highly flexed in No. 20. The center of foot pressure was at the ball of the sole. The knee and the ankle were flexed a

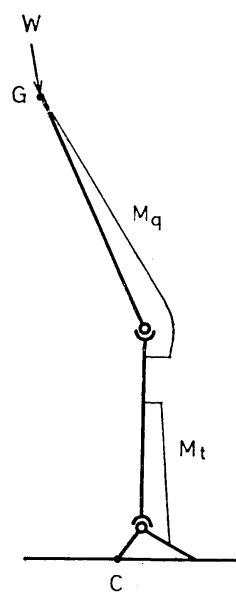

(a)

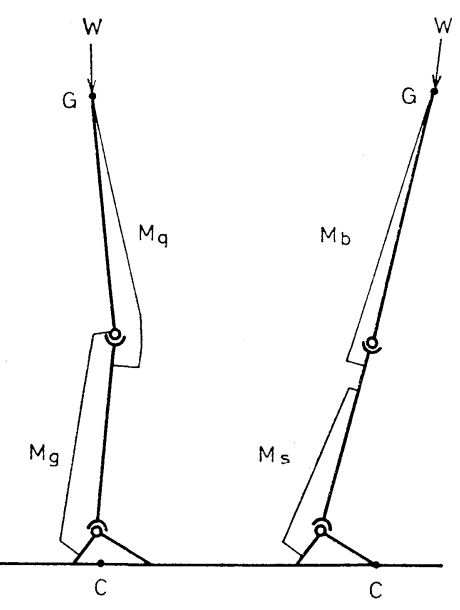

(b)

(c)
Fig. 3. Phases in walking.
a. No. 13 .
b. No. 16 .
c. No. 20 .

Numbers from the diagram of BRAUNE and FISCHER (1895), 1st trial.

$\mathrm{Mb}$; the biceps femoris and the semimembranosus and semitendinosus. Mt; the tibialis anterior. $\mathrm{Mg}$; the gastrocnemius. $\mathrm{Mq}$; the quadriceps femoris. Ms; the soleus. G; center of body weight. C; center of foot pressure. W; body weight, in this paper $60 \mathrm{~kg}$. When tibia was impressed by normal force only, it was $30 \mathrm{~kg}$., that is one second of the usual body weight. little in No. 16. The center of foot pressure was at the middle of the sole. The walking posture might be represented by these three phases which are illustrated in Fig. 3. In every phases of the diagram, all forces and moments in the body must balance statically. The magnitude of the normal and shearing forces acting on both articular surfaces and the tensile intensity of muscle forces were calculated, when the body posture and the direction and attaching areas of muscle forces were known. The diagrams of BRAUNE-FISCHER may not always be reliable. I am trying another analysis from our own experiments on walking which will appear elsewhere. 


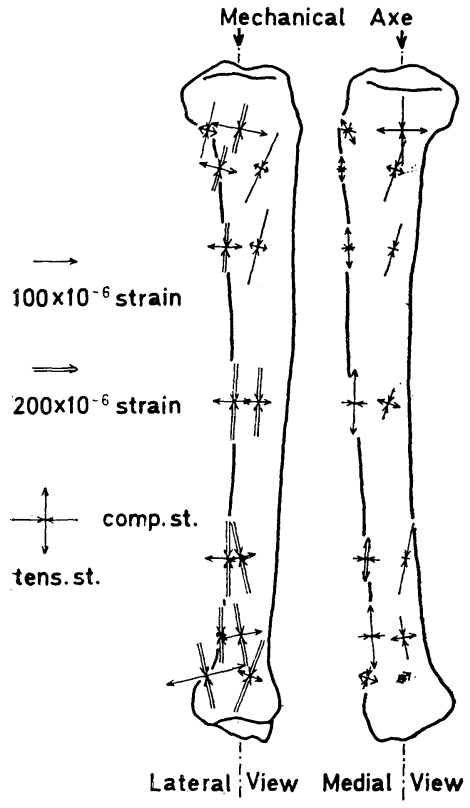

(a)

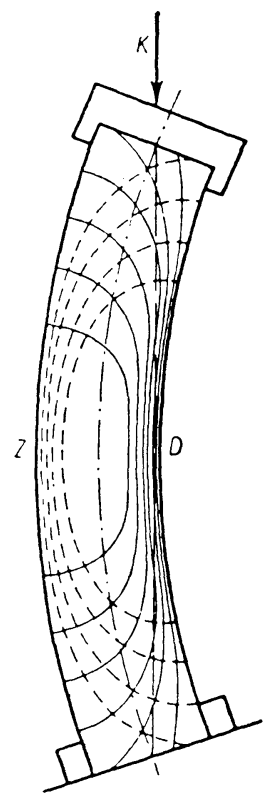

(b)

Fig. 4. Similarity between principal strains of the tibia and those of the curved column under the axial force only.

a. tibia. b. curved column (from PAUWELS 1954).

$D$; compressive strain. $Z$; tensile strain.

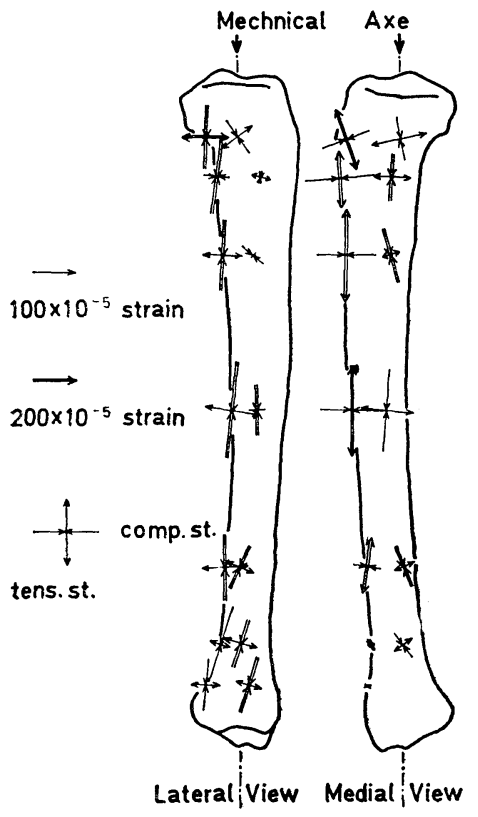

(a)

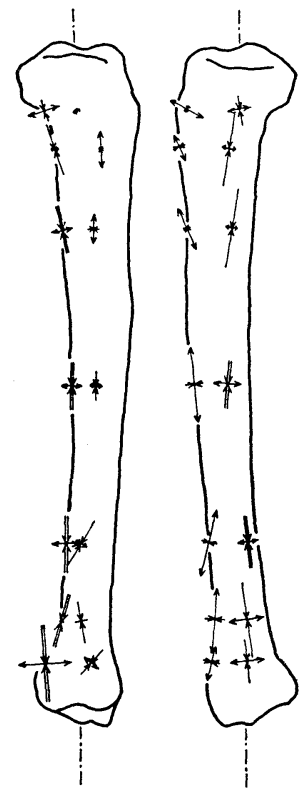

(b)

\section{RESULTS}

Principal strains on the surface of tibia under the axial compression are shown in Fig. 4-a. There were tensile strains on the anterior surface of the shaft and compressive strains on the posterior surface, both approximately in the longitudinal direction.

The principal strains on the surface of the tibia in three walking phases are shown in Fig. 5. The anterior surface of the shaft was elongated and the posterior surface was contracted in No. 13 , in which the forces corresponding to the quadriceps femoris and the tibialis anterior were acting. The tibia had a tendency

Fig. 5. Principal strains of the tibia in walking.

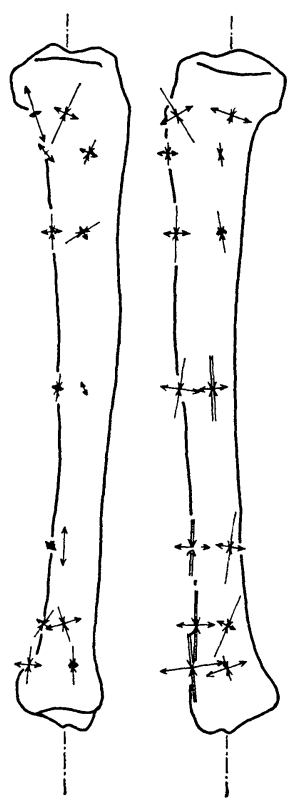

(c) a. No. 13 . b. No. 16 . c. No. 20 
to curve forwards. On the contrary, there were tensile strains on the posterior surface of the shaft and compressive strains on the anterior surface in No. 20, in which the forces corresponding to the soleus, the biceps femoris and the semimembranosus and semitendinosus were acting. In this phase the tibia tended to curve backwards. It had a tendency to curve forwards slightly in No. 16, in which the forces corresponding to the quadriceps femoris and the gastrocnemius were acting.

On both ends of the tibia, the principal strains were not in the longitudinal direction in every phase.

Longitudinal strains in horizontal section under the axial force are shown in Fig. 6-a. The longitudinal strains at every level of the tibia looked like those of the elliptical pipe eccentrically loaded (Fig. 6-b). The largest strains were seen near the anterior and the posterior margins of the shaft and the neutral line followed the mesio-lateral direction.

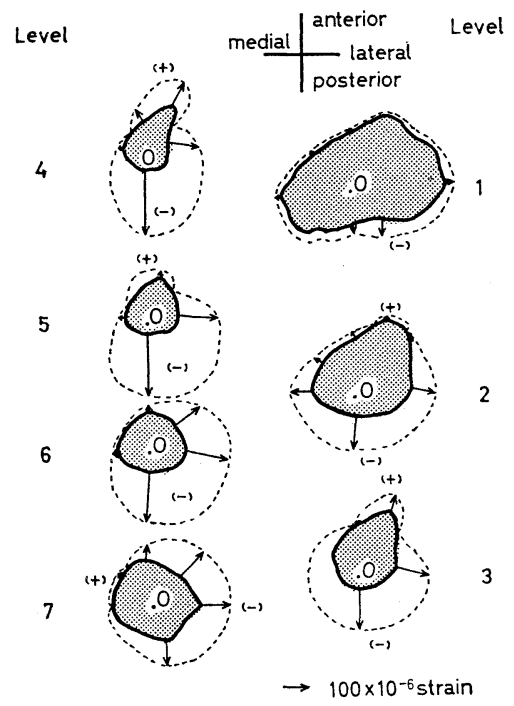

(a)
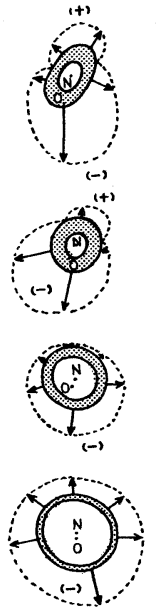

(b)
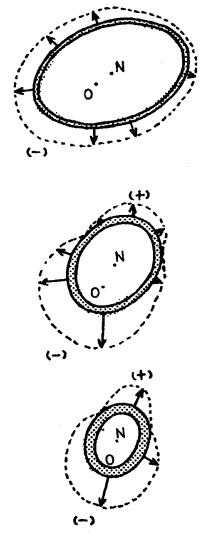

$\rightarrow 100 \times 10^{-6}$ strain

Fig. 6. Longitudinal strains under the axial force.

a. strains of the tibia measured by the experiment.

b. strains of elliptical pipe culculated by the mathematical analysis.

Cross sections of the pipe are so made to be similar to the section of

the tibia. The pipe is eccentrically loaded with $30 \mathrm{~kg}$. weight.

$\mathrm{O}$; loading point. $\mathrm{N}$; centroid. $(+)$; tensile strain. $(-)$; compressive strain.

Longitudinal strains in three phases of walking are shown in Fig. 7. In every phase, there were the largest strains near the anterior and the posterior margins of the shaft. There appeared tensile strains on the anterior surface and compressive ones on the posterior surface in cases of No. 13 and No. 16. There were tensile strains on the posterior surface and compressive ones on the anterior 
Levei Level

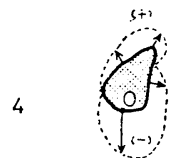

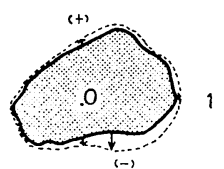

E

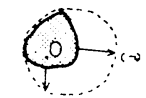

6

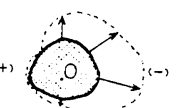
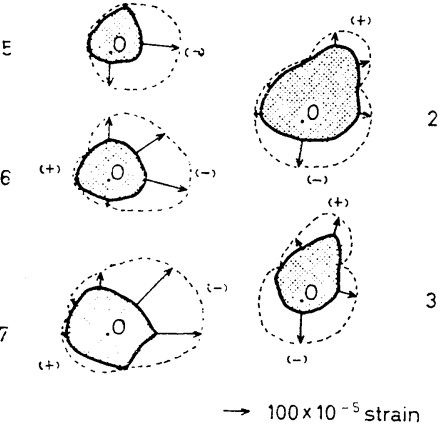

(a)
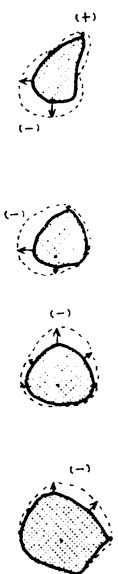
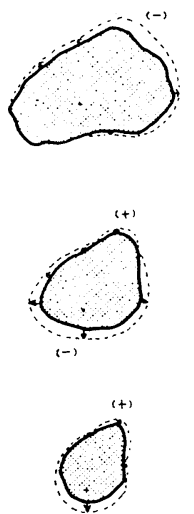

$(-)$
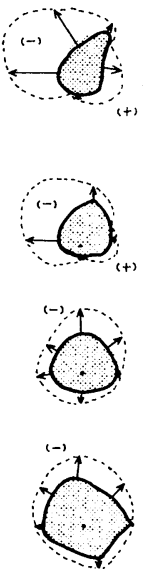
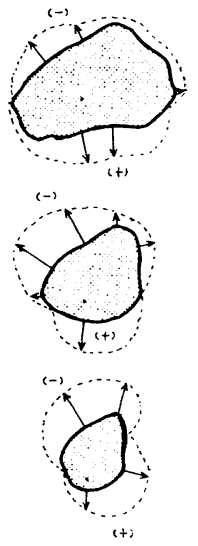

(b)

(c)

Fig. 7. Longitudinal strains of the tibia in walking.

a. No. 13 b. No. 16 . c. No. 20 .

O; mechanical axis. $(-)$; tensile strain. $(-)$; compressive strain.

surface in No. 20.

On the upper and lower ends of the tibia, the largest strains did not appear near the anterior and the posterior margins, but near the internal and the external margins. There were generally compressive strains around the bone.

\section{DISCUSSION}

Forces acting on the tibia are axial compression, bending force and shearing force. These forces are caused by the body weight and muscular forces of the lower limbs. Bending force follows sagittal direction because of the location of the attaching areas of muscles and directions of articlar movements. The magnitude and position of the body weight, the area of muscular attachments and movement of joint may be concerned with the bone functions.

The tibia must be a straight column as is seen in case of the cannon bone of the horse, if its role is to resist the axial compression only. Uniform compressive strains appear around the surface of such column. The distribution of strains around the tibia is unequal, unike that of the straight column, because it curves forwards. The distribution of directions of principal strains is rather similar to that of the curved column under the normal force (Fig. 4).

When muscles of the lower limbs are acting in walking, the tibia is forced to curve. The largest strains can be seen about the anterior and the posterior border on the shaft (Figs. 5 and 7 ). The tibia can resist these strains more 
easilly, as the largest diameter in horizontal section also nearly points the anteroposterior direction on the shaft. KNESE et al. (1954) and PAUWELS (1950) have shown the largest moment of inertia of area on the shaft in the sagittal plane. When muscles of the leg, which are the tibialis anterior, the quadriceps femoris etc., act stronger and more often, the longer antero-posterior diameter will be better to support them.

It may be convenient for the tibia that the attaching area of quadriceps femoris is prominented forwards when the knee joint is flexed. It may be inconvenient, however, to curve forwards when muscles on anterior surface are working. Because they will cause larger tensile strains on the anterior margin than those caused by axial force only (Figs. 5-a, 5-b, 7-a and 7-b). When muscles of the lower limbs on the posterior surface are working, there will be compressive strains of the anterior margin of the shaft (Figs. 5-c and 7-c). Tensile and compressive strains appear alternately over again on the anterior and the posterior margins in walking. The shaft of the tibia may not be adapted for one static phase, but for the dynamic movement under the continual changes.

On both ends of the tibia the largest strains do not appear near the anterior and the posterior margins, but the internal and the external margins. It may be chiefly because of the way of impression acting on articular surfaces. The largest diameter of two ends of the tibia follows also mesio-lateral direction, as the largest strains appear in the position where the largest diameter points to the anteroposterior direction on the shaft. KNESE et al. (1954) also mentioned that the largest moment of inertia of area on the lower end lay in the frontal plane.

More muscles than those acted in the experiment may be working actually in the living body. But the principal mechanical phenomena in tibia in walking may be clarified by this experiment.

The tibia may be acted on by more intensive forces in jumping, running and so on than in walking. In the former cases the patterns of strains in the tibia may be about the same as those in the latter. It is because the kind of the acting muscles may be identical, although their intensity are different.

\section{SUMMARY}

The functional analysis of the form of human tibia was made by means of the method of mechanical experiments of intact bone with wire strain gages. Results are shown in Figs. 4, 5, 6 and 7.

Conclusions are summarized as follows:

1) The shaft of tibia does not seems to be profitable to support the body weight pointing axial direction only, but to be adapted to resist the forces which are produced when muscles of lower limbs are acting as seen in walking. 
2) The shape of horizontal sections of the tibia is adapted to resist the bending force caused chiefly by muscle tention. The largest diameter points to the place where the largest strains appear.

I wish to express my gratitude to Prof. Hisashi Suzuk of Department of Anthropology, Faculty of Science, University of Tokyo for his continuous guidance. I also wish to express my thanks to Prof. Teruyoshi Utoguchi, Associate Prof. Hiroyuki Okamura and Mr. Shunsaku Mrtsuhashi of Department of Mechanical Engineering, Faculty of Engineering, University of Tokyo for their valuable advices. Thanks are also expressed to Department of Anatomy, Faculty of Medicine, University of Tokyo for making facilities for my experimental materials.

\section{REFERENCES CITED}

Braune, W. and O. Fischer, 1895: Der Gang des Menschen. 1 Theil. Leipzich.

Evans, F.G., 1953: Methods of studying the biomechanical significance of bone form. Am.

J. Phys. Anthrop., 11. pp. 413-436.

FICK, R., 1911: Handbuch der Anatomie und Mechanik der Gelenk. 3 Theil. Jena.

Fischer, O., 1899: Der Gang des Menschen. 2 Theil. Leipzich.

KNESE, K. H., O. H. HAHNE and H BIERMANN, 1954: Festichkeitsuntersuchungen an menschlichen Extremitätenknochen. Morph. Jb., 96. pp. 141-209.

KNesE, K. H., 1955: Statik des Kniegelenkes. Z. Anat. Entwickl. Gesch., 118. pp. 471-512. KOCH, J.C., 1917: The laws of bone architecture. Am. J. Anat., 21. pp. 77-298.

KONDO, S., 1952: The experimental study on walking, mainly from the point of view of the action current of muscle. J. Anthrop. Soc. Nippon, 62. pp. 121-129.

Kondo, S., 1960: Anthropological study on human posture and locomotion mainly from the view point of electromyography. J. Fac. Science, Univ. Tokyo, Sec. 5, Vol. 2, Pt. 2, pp. 189-260.

KUMmER, B., 1959: Bauprinzipien des Säugerskeletes. Stuttgart.

Kummer, B., 1965: Die Biomechanik der aufrechten Haltung. Mitteil. Naturfor. Gesell. Bern, N. F. 22. pp. 239-258.

MochizUKi, T., 1965: Electromyographic study on paralytic gait. J. Jap. Orthop. Ass., 39. pp. 219-235.

PaUwels, F., 1950: Die Bedeutung der Muskelkräfte für die Regelung der Beanspruchung des Röhrenknochens während der Bewegung der Glieder. Z. Anat. Entwickl. Gesch., 115. pp. 327-351.

PAUWELS, F., 1954: Beschreibung und Erläuterung einer knöchernen Kniegelenksankylose. Z. Anat. Entwickl. Gesch. 117. pp. 528-552.

Roux, W., 1883: Beiträge zur Morphologie der functionellen Anpassung. 1, Structur eines hochdifferenzirten bindegewebigen Organes. Arch. Anat. Physiol. Jb. 1883. pp. 76-162.

Wolff, J., 1892: Das Gesetz der Transformation der Knochen. Berlin. (cited in EvaNs, 1953)

Department of Anthropology,

Faculty of Science,

University of Tokyo 
力学的にみたヒトの脛骨形態の実験的研究

木村賛

骨の形態と機能との関係についての研究は，今まで主にヒトの大腿骨に関して行われてきた。しかし脛 骨に関しては数学的分析は行われても, 実際の骨について実験的研究が行われたてとは少かつた。

この論文では，生体におけると類似した力を脛骨に与える実験により，骨にひきおこされる歪を実際に 測定し，分析することが行わ机た。資料としては現代日本人䁌骨 4 本が用いられた。脛骨の主な機能は歩 行であると考えられる。乙の時に加わる力に近似させた力が荷重装置により資料に加えられた。対象とし て軸方向圧縮力のみを加える実験む行われた。乙れらの実験の際に脛骨表面に生ずる主碓の方向と大きさ の分布, 及び軸方向泵の大きさの分布が strain gage により測定された。その結果は図 4,5,6,7 に示さ れている。

結論は以下の通りである。

1）脛骨骨体は軸方向にのみ加わる体重を支えるには不適であり，歩行の際のごとく下肢筋が働いている ときの力に対抗するに適した形態をしている。

2）脛骨水平断面の形態は脛骨を曲げようとする力を支えるに適している。最大の歪は最大径のある位置 に現れる。

(東京大学理学部人類学教室) 